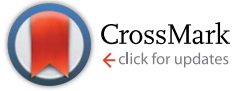

Cite this: RSC Adv., 2017, 7, 16460

Received 31st January 2017

Accepted 2nd March 2017

DOI: $10.1039 / c 7 r a 01309 d$

rsc.li/rsc-advances

\section{Novel eco-friendly biocatalyst: soybean peroxidase immobilized onto activated carbon obtained from agricultural waste}

\author{
J. A. Torres, ${ }^{\star a}$ F. G. E. Nogueira, ${ }^{\text {b M. C. Silva, }}{ }^{\text {c }}$ J. H. Lopes, ${ }^{\text {d }}$ T. S. Tavares, ${ }^{a}$ \\ T. C. Ramalho and A. D. Corrêa $a^{a}$
}

The immobilization of enzymes is an excellent alternative to overcome the drawbacks of using these biocatalysts in free form. This process plays a significant role in cost-effective recovery, increased catalyst productivity and in simplifying process operations. After the soybean peroxidase (SP) extraction, a residue at high carbon and low ash content is generated. This residue was used as carbonaceous precursor for production of carbon activated (AC) with high surface area $\left(1603 \mathrm{~m}^{2} \mathrm{~g}^{-1}\right)$. The AC produced was used as support for SP immobilization. The immobilization of SP was evaluated in different time conditions, enzyme load, $\mathrm{pH}$ and temperature. The samples, before and after immobilization, were characterized by thermogravimetric analysis, elemental analysis composition, specific surface area, X-ray powder diffraction, scanning electron microscopy and Fourier transform infrared spectroscopy. In addition, repeated applications of immobilized biocatalyst were made in order to evaluate its operational stability and capacity to recover the reaction medium, in which was observed that after a decline in activity from the first to the second cycle, it remained constant until the tenth application. In the context, the process of material obtainment constitutes a clean route for the development of more sustainable biocatalysts capable of applications in various areas.

\section{Introduction}

Enzymes are biocatalysts widely used in several areas, including the synthetic, pharmaceutical chemistry, wastewater bioremediation, fabrication of high performance biosensors, among others. $^{\mathbf{1 - 5}}$ They exhibit a high catalytic activity and selectivity, acting as an environmentally efficient catalyst without the need to work at high pressures, temperatures and harsh chemical environments. However, their use still is hampered due to some limitations related to their low stability front a $\mathrm{pH}$, temperature, loss of activity due to the changes in environmental conditions and presence of the interferents, as well as the impossibility of reuse. The high cost associated with their production and purification, their fragile nature highly dependent on the reaction conditions and high loads required for commercial production are factors that hamper their free-form application. ${ }^{6-8}$ Due to these factors, the immobilization of enzymes has been an industrially and commercially viable alternative,

${ }^{a}$ Department of Chemistry, Universidade Federal de Lavras, Lavras, 37200-000, Brazil. E-mail: julianaarriel@hotmail.com

${ }^{b}$ Department of Chemistry Engineering, Universidade Federal de São Carlos, São Carlos, 13565-905, Brazil

${ }^{c}$ Department of Chemistry, Universidade Federal de Minas Gerais, Belo Horizonte, 31270-901, Brazil

${ }^{d}$ Department of Physical Chemistry, Universidade de Campinas, Campinas, 13083970, Brazil solving the disadvantages of their use in solution related to stability and recovery of the reaction medium.

The enzyme immobilization process may lead to an improved specificity and especially the catalyst stabilization, protecting the enzymes from denaturants agents and proteolysis. ${ }^{9,10}$ Several authors have describe processes of immobilization of different enzymes in various carriers which can be achieved by physical methods, that involve the entrapment of enzyme molecules within a porous matrix, and chemical methods, which, in turn, include enzyme attachment to the matrix by covalent bonds, cross-linking between enzyme and matrix, or enzyme cross-linking by multi-functional reagents. ${ }^{7,8,11-14}$ Among the various techniques used for the immobilization of enzymes, we can highlight adsorption, a simple, fast and economically viable process that can occur through physical interactions generated between the enzyme and the carrier. The physic-chemical parameters of the carrier that should be taken into an account are the surface area, pore structure and type of functional groups present on the surface. Adsorbed enzymes are shielded from aggregation, proteolysis and interaction with hydrophobic interfaces. In this process, the bond between the enzyme and the carrier is relatively weak compared to the chemical immobilization. That is very interesting, since the native structure of the enzyme is not altered enabling it to maintain its activity. ${ }^{7,11,15}$

In general, the carriers used for the enzyme immobilization by adsorption can be divided into both organic and inorganic 
origin. Among the various organic carriers used, the use of activated carbon can be emphasized, which presents a large surface area, a high pore volume and higher hydrothermal resistance compared to other porous materials. In addition, the immobilization process in this matrix is nontoxic, fast, inexpensive, easy to handle and stable against denaturation by oxidants. $^{8,16}$

The search for different precursors for the synthesis of activated carbon has been increasing and the use of agro-industrial waste makes the process even more viable economically, besides meeting current environmental needs. Consequently, various types of precursors of vegetable origin have been researched, such as wood, apricot and/or cherry pits, wheat straw, bean and rice husks, nut husks, corn husks, among others. ${ }^{17}$ The soybean seed hulls are an abundant waste from soybean-processing industries and may offer an inexpensive and renewable additional source of activated carbons. Thus, conversion of this kind of waste in active carbon reduces the cost of waste disposal and provide an alternative to the existing commercial active carbon. ${ }^{\mathbf{1 8}}$

Peroxidases (E.C.1.11.1.7) are enzymes that catalyze the reduction of peroxides, such as hydrogen peroxide and the oxidation of a variety of organic and inorganic compounds, such as, phenolic compounds, aromatic amines and dyes and, therefore, they have a great potential as bioremediation catalysts. ${ }^{19}$

Thus, the focus of this work was to synthesize an activated carbon from residue originating from enzymatic extraction of an agribusiness byproduct, optimize soybean peroxidase immobilization parameters in the activated carbon obtained and to evaluate the reuse of the immobilized biocatalyst in order to obtain a capable environmental friendly biocatalyst for applications in numerous technological areas.

\section{Experimental}

\section{Obtention of soybean peroxidase (SP)}

Initially the soybean seeds were immersed in distilled water for $24 \mathrm{~h}$ and then the husks were removed manually (Fig. 1). The process of obtaining the biocatalyst was conducted according to Silva et al. ${ }^{19}$ The peroxidase activity assay was based on the rate of guaiacol oxidation for the formation of tetraguaiacol $(\varepsilon=26.6$ $\mathrm{mM}^{-1} \mathrm{~cm}^{-1}$ ). One unit of peroxidase activity at $\mathrm{pH} 6.0$ represents the oxidation of $1 \mu \mathrm{mol}$ of guaiacol $\times \min ^{-1} .^{20}$

\section{Activated carbon preparation}

The waste originating from the process of obtaining the soybean peroxidase was used as a carbonaceous precursor for synthesis

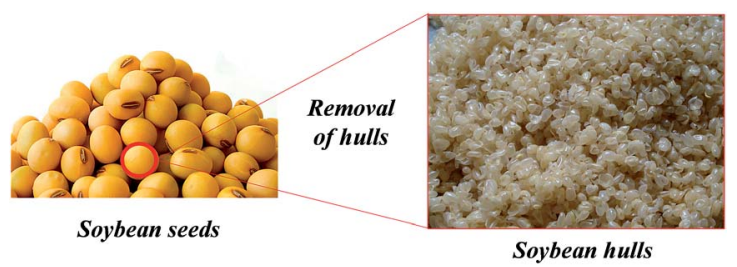

Fig. 1 Removal of soybean hulls. of activated carbon. This waste was washed with distilled water successive times to remove excess phosphate buffer $\mathrm{pH}$ 6.5, dried at $60{ }^{\circ} \mathrm{C}$ for $24 \mathrm{~h}$ and then treated with a zinc chloride $\left(\mathrm{ZnCl}_{2}, 97 \%\right.$ P. A. Sigma-Aldrich) solution at a $1: 1$ mass proportion (salt : raw material) and pyrolyzed in a tubular oven, under a $\mathrm{N}_{2}$ flow of $150 \mathrm{~mL} \mathrm{~min}^{-1}$, at $550{ }^{\circ} \mathrm{C}$, for $3 \mathrm{~h}$. The material was then washed with hot distilled water for $1 \mathrm{~h}$ to remove the excess activating agent and dried at $60{ }^{\circ} \mathrm{C}$ for $24 \mathrm{~h}$.

\section{Adsorption experiments (immobilization of soybean peroxidase)}

For the immobilization process, $1 \mathrm{~g}$ of activated carbon was kept under constant stirring in a water bath with $20 \mathrm{~mL}$ of SP solution in buffer. The following parameters were evaluated: time (30 $\mathrm{min}$ to $300 \mathrm{~min}$ ), enzyme load $(0.05,0.1,0.25,0.5$ and $1 \mathrm{~g}$ ), $\mathrm{pH}$ (3-6 citrate phosphate buffer, 7-9 tris- $\mathrm{HCl}$ buffer) and temperature $\left(20\right.$ to $\left.70{ }^{\circ} \mathrm{C}\right)$. To assist in understanding the enzyme immobilization process at different $\mathrm{pH}$ values, the $\mathrm{pH}$ corresponding to the point of zero charge $\left(\mathrm{pH}_{\mathrm{PCZ}}\right)$ for the $\mathrm{AC}$ was determined. The zeta potential of the dilute suspensions of the materials was measured in a Zeta Potential Meter (Malvern Zeta Sizer model nano-ZS) in a $\mathrm{pH}$ range of 9.7 to 3.0 , the $\mathrm{pH}$ value was adjusted by adding $\mathrm{HCl}\left(0.1 \mathrm{~mol} \mathrm{~L}^{-1}\right)$ or $\mathrm{NaOH}$ $\left(0.1 \mathrm{~mol} \mathrm{~L}^{-1}\right)$. The immobilization procedure was stopped by separation of the immobilized material by centrifugation at $11000 \times g$, for $10 \mathrm{~min}$ at $25^{\circ} \mathrm{C}$. After the procedure, the material obtained was washed under vacuum with citrate-phosphate buffer $\mathrm{pH} 6.0$ to remove excess unbound enzyme, and then dried at $4{ }^{\circ} \mathrm{C}$ overnight, and finally stored in a freezer. The immobilized material was called SP-AC.

Immobilization of SP was investigated by measurements of enzymatic activity according to Khan and Robinson. ${ }^{20}$ The immobilization yield was calculated from the difference between the initial and residual activity according to the following eqn (1): ${ }^{21,22}$

$$
\varphi_{(\%)}=\left(A_{0}-A_{\mathrm{F}}\right) / A_{0} \times 100
$$

where: $\varphi_{(\%)}$ is the immobilization yield, $A_{0}$ is the enzyme activity of the supernatant before incubation, and $A_{\mathrm{F}}$ is the enzyme activity of the supernatant after the incubation period.

\section{Characterization}

Thermogravimetric analysis (TG). The AC and SP-AC were characterized by thermogravimetric analysis (TG) to determining the ash content. TG analysis (10 $\mathrm{mg}$ of sample) were performed on a TG/DTA 6200 simultaneous TG/DTA thermogravimetric analyser (TG/DTA 6200, SII NanoTechnology Inc., Tokyo, Japan). Samples were heated under air (100 $\left.\mathrm{mL} \mathrm{min}^{-1}\right)$ from room temperature to $1000{ }^{\circ} \mathrm{C}$ at $10{ }^{\circ} \mathrm{C} \mathrm{min}{ }^{-1}$. The weight loss (TG curve) and the derivative weight loss (DTG curve) were recorded as a function of temperature.

Elemental analysis composition ( $\mathrm{CHN})$, specific surface area, total pore volume and average pore diameter. The determination of carbon, hydrogen and nitrogen in the carbonaceous precursor and the activated carbon were performed in triplicate, 
using $10 \mathrm{mg}$ of sample in a CHN elemental analysis equipment from Perkin Elmer 2400. The samples were weighed in tin capsules using a microbalance (Perkin Elmer AD-6 Auto Balance Controller) connected to $\mathrm{CHN}$ for direct acquisition of the masses. All results are based on a value of a standard of known elemental composition.

The specific surface area, total pore volume and average pore diameter were determined by physical $\mathrm{N}_{2}$ adsorption/ desorption at $77 \mathrm{~K}$ using a Quantachrome Nova 1200 instrument. Prior to each analysis the materials were degassed at $250{ }^{\circ} \mathrm{C}$ under vacuum for $5 \mathrm{~h}$. The total pore volume was calculated at a relative pressure at $P / P_{0} \approx 0.985$.

X-ray powder diffraction (XRD). XRD pattern of materials was analyzed by X-ray powder diffraction (XRD) using a diffractometer (XRD-7000, Shimadzu Scientific Instruments, Tokyo, Japan) with a Bragg Brentano camera geometry, $\mathrm{Cu}-\mathrm{K}_{\alpha}$ incident radiation $(\lambda=1.5418 \AA), 40 \mathrm{kV}, 30 \mathrm{~mA}$ and acquisition rate of $2^{\circ}$ $\min ^{-1}$ between 10 and $60^{\circ}(2 \theta)$ range.

Scanning electron microscopy (SEM). The morphology was investigated by scanning electron microscopy (FEI QUANTA FEG 250 ESEM, FEI Company, Hillsboro, Oregon, USA). Samples were carbon coated using carbon thread on a sputtercoater (BALTEC Maschinenbau AG Med model 020, Pfaffikon, Switzerland) with a carbon evaporative attachment prior to Secondary Electron Imaging (SE).

Fourier transform infrared spectroscopy (FTIR). Surface groups of the materials (SP, AC and SP-AC) were characterized by Fourier transform infrared spectroscopy (FTIR) on an interferometric spectrometer operating with a ceramic bright light source and high-sensitivity DLATGS detector (Shimadzu Prestige-21, Shimadzu Corporation, Tokyo, Japan). The Happ-Genzel function was used to achieve a good balance between ripple size and resolution. ${ }^{23}$ CsI pellets were prepared by mixing $1 \mathrm{mg}$ of filtered powders with $100 \mathrm{mg}$ of cesium iodide. FTIR spectra were acquired in the 4000-300 $\mathrm{cm}^{-1}$ region with spectral resolution of $2 \mathrm{~cm}^{-1}$ and 128 scans. During all analyses, the IR system was continuously purged with $\mathrm{N}_{2}$ gas to reduce the interference due to water vapor and carbon dioxide.

Operational stability of immobilized enzyme. The operational stability of the SP-AC was determined by repeated applications of the immobilized enzyme in the enzyme activity assay. After each cycle, the activated carbon containing the immobilized enzyme $(20 \mathrm{mg})$ was removed by centrifugation at $11000 \times g$ for $2 \mathrm{~min}$ at $20^{\circ} \mathrm{C}$, washed with citrate phosphate buffer $\left(0.1 \mathrm{~mol} \mathrm{~L}^{-1}\right) \mathrm{pH} 6.0$ to remove excess unbound enzyme before the next cycle. The washing residue of SP-AC was collected and the residual enzymatic activity was determined. Then, the SP-AC was dispersed again in a fresh reaction medium.

\section{Results and discussion}

Effect of time and enzyme load on the immobilization process

The effect of time on the enzyme immobilization process was evaluated in order to determine the equilibrium point, from which the yield of immobilization is maximum. According to
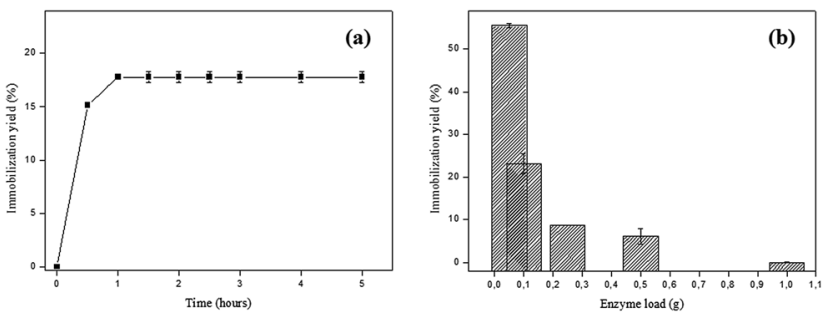

Fig. 2 (a) Effect of time on the SP immobilization process in AC. Reaction conditions: initial enzyme load - SP $2.31 \mathrm{U} ; 1 \mathrm{~g}$ of activated carbon, $\mathrm{pH} 6.0,30{ }^{\circ} \mathrm{C}$; (b) effect of enzyme load on the SP immobilization process in $\mathrm{AC}$. Reaction conditions: $1 \mathrm{~g}$ of activated carbon, $\mathrm{pH}$ $6.0,30{ }^{\circ} \mathrm{C}$ for $1 \mathrm{~h}$.

Fig. 2a it can be observed that from $1 \mathrm{~h}$ the immobilization yield is not changed, keeping constant until $5 \mathrm{~h}(\approx 17.75 \%)$.

At the beginning of the process there is a high number of available adsorption sites and the mass transfer is favored. The extent that SP molecules are adsorbed to the bare sites becomes scarce and therefore less available, causing the enzymes to become clustered decreasing the immobilization yield. This may explain why, after a certain time, the immobilization process becomes constant. ${ }^{8}$ Based on these data, the time of $1 \mathrm{~h}$ was maintained for the next immobilization experiments.

The second parameter evaluated was the variation of enzyme loading and the optimal enzyme load found was $0.05 \mathrm{~g}$ SP (in 20 $\mathrm{mL}$ phosphate citrate buffer $\mathrm{pH}$ 6.0), with immobilization yield of $55.52 \%$, whereas using $1 \mathrm{~g}$ SP the yield was practically zero (Fig. 2b). The immobilization yield is greater at low enzyme loads, suggesting that lower yields may be associated with agglomeration of enzymes near the pore entrances and the active sites of the support used. ${ }^{24}$ Liu and coworkers ${ }^{\mathbf{1 6}}$ found similar results which suggest that the resulting steric constraints could interfere in the dispersion of enzyme molecules on the activated carbon surface, which can be observed by the immobilization yield decrease.

Jain and coworkers ${ }^{25}$ also evaluated the effect of horseradish peroxidase (HRP) loadings on surface-modified mesoporous active carbon (SMAC) for different initial values of the enzyme : substrate ratio. For all ratios studied, the immobilization decreases with increasing enzyme : support ratio. Analyzing the commercial activated carbon as support for immobilization of horseradish peroxidase in a higher ratio ( $1 \mathrm{mg}$ of HRP : $0.1 \mathrm{~g}$ SMAC) the percentage of HRP loading was $49.9 \%$.

\section{Effect of pH and temperature on the immobilization process}

In order to evaluate the optimum $\mathrm{pH}$ for the immobilization of $\mathrm{SP}$ on $\mathrm{AC}$, the $\mathrm{pH}$ of the enzyme solution ranged from 3 to 9. The higher immobilization yield $(86.17 \%)$ was obtained at $\mathrm{pH} 3.0$, which may be related to the surface charge on the adsorbent and the enzyme (Fig. 3a).

The functional group and delocalized electrons present in the activated carbon is that which will characterize the acidic or basic character of its surface. Thus, the modification of $\mathrm{pH}$ of the liquid phase strongly influences the surface properties of activated carbon. The surface of the adsorbent is neutral 

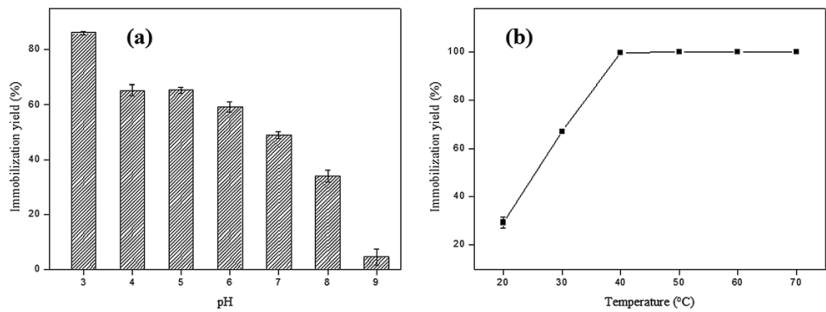

Fig. 3 (a) Effect of $\mathrm{pH}$ on the SP immobilization process in $\mathrm{AC}$ Reaction conditions: $1 \mathrm{~g}$ of activated carbon, $0.05 \mathrm{~g}$ of SP, $30^{\circ} \mathrm{C}$ for $1 \mathrm{~h}$; (b) effect of temperature on the SP immobilization process in AC. Reaction conditions: $1 \mathrm{~g}$ of activated carbon, $0.05 \mathrm{~g}$ of SP, pH 3.0, for $1 \mathrm{~h}$

(surface charge equal to zero) when the solution $\mathrm{pH}$ is equal to point of zero charge (PCZ). The surface is negatively charged at $\mathrm{pH}$ values greater than $\mathrm{pH}_{\mathrm{PCZ}}\left(\mathrm{pH}>\mathrm{pH}_{\mathrm{PCZ}}\right)$, and positively charged at $\mathrm{pH}$ values lower than $\mathrm{pH}_{\mathrm{PCZ}}\left(\mathrm{pH}<\mathrm{pH}_{\mathrm{PCZ}}\right){ }^{41}$ The $\mathrm{pH}$ at the point of zero charge found for the $\mathrm{AC}$ obtained in this study was 7.36. Thus, at $\mathrm{pH}$ values in the 3 to $6\left(\mathrm{pH}<\mathrm{pH}_{\mathrm{PCZ}}\right)$ range of the AC surface is positively charged, while at $\mathrm{pH}$ values 8 and 9 , the AC surface is negatively charged $\left(\mathrm{pH}>\mathrm{pH}_{\mathrm{PCZ}}\right)$.

Peroxidases are classified into three superfamilies: plant peroxidase, animal peroxidase and catalase peroxidase. The plant peroxidase superfamily is further subdivided into three classes: Class I, the intracellular peroxidases; Class II, which consists of extracellular fungal peroxidases and Class III, which comprises the plant class. ${ }^{26}$ However, the three peroxidases classes show low identity in their primary amino acid sequences and have distinct functions and reaction mechanisms. It is important to highlight that plant peroxidases contain isoforms different, and because of this factor, it is generally difficult to determining the isoelectric point of a specific isoform of peroxidase, mainly because protein purification is not straightforward. ${ }^{27}$ In this way, it is inferred that at $\mathrm{pH}$ values > $\mathrm{pH}_{\mathrm{PCZ}}$ where the immobilization yield was less pronounced, the enzyme was negatively charged, which can have led to an electrostatic repulsion between the adsorbent surface and the enzyme. On the other hand, at $\mathrm{pH}$ values $<\mathrm{pH}_{\mathrm{PCZ}}$ the observed effect was the opposite, with an increase in the immobilization percentage.

The next step in the evaluation of the optimal parameters consists in the evaluation of the effect of temperature on the immobilization of soybean peroxidase in activated carbon. This effect was evaluated at different temperatures and the $\mathrm{pH}$ maintained constant at 3.0.

The last parameter analyzed during the SP immobilization process in $\mathrm{AC}$ was temperature, and the results obtained are shown in Fig. 3b. An increase was observed of the immobilization yield with increasing the temperature from 20 to $50{ }^{\circ} \mathrm{C}$, reaching $100 \%$ at $40{ }^{\circ} \mathrm{C}$. After this temperature, the immobilization percentage remained constant up to $70{ }^{\circ} \mathrm{C}$. At high temperatures the diffusion rate of the enzyme molecules increases through the external boundary layer and in the internal pores of the adsorbent as a function of the solution viscosity decrease, besides acquiring sufficient kinetic energy to interact with the active sites of the surface..$^{28,29}$
From the results obtained in this manuscript, the best conditions for soybean peroxidase immobilization in activated carbon were obtained in a period of $1 \mathrm{~h}$, with an enzyme: support ratio of $0.05: 1 \mathrm{~g}, \mathrm{pH} 3.0$ (citrate-phosphate buffer) at temperature of $40{ }^{\circ} \mathrm{C}$.

\section{Characterization}

CHN analysis and specific surface area, average pore diameter and total pore volume of materials. The elemental compositions of the carbonaceous precursor, AC and SP-AC are presented in Table 1. The carbon content found in the precursor was $38.84 \%$, close to that found by Gonçalves and coworkers, ${ }^{30}$ which makes the residue used an excellent precursor for activated carbon synthesis, since the carbon content is one of the fundamental parameters for the development of a material with a high surface area and porosity. In addition, it is important to note that the decrease in the hydrogen content in AC compared to the precursor may be associated with the release of volatile compounds during the pyrolysis process.

The AC production from waste generated during the enzyme extraction process presents a high specific surface area $1603 \mathrm{~m}^{2}$ $\mathrm{g}^{-1}$ and total pore volume $0.847 \mathrm{~cm}^{3} \mathrm{~g}^{-1}$ with the average pore diameter obtained being $15.96 \AA$. In the adsorption process there is little control over the orientation of the enzyme in the pores of the support. However, some amino acid residues may interact more favorably with the pore walls by acquiring a certain orientation. In addition, the pore size can also force a certain orientation. The enzyme immobilization efficiency and its retention is directly dependent on enzyme size and pore diameter of the carrier. ${ }^{31}$

It is worth mentioning that the cost of supports for enzyme immobilization is one of the essential factors to know the economic feasibility of their use, which may be related to several factors, including the cost of the precursor used (natural agroindustrial byproducts, or synthesized products) and it availability. ${ }^{32}$ In addition, the obtaining of the catalyst described in this work complies with the principles of green chemistry, ${ }^{33}$ since the waste generated during the enzyme extraction process is repurposed, which makes it a process with zero residue generation.

Scanning electron microscopy (SEM). SEM images of precursor (waste from the enzyme extraction process) and activated carbon before and after SP enzyme immobilization are shown in Fig. 4a-d. The micrographs of the precursor show skeletons with clearly identifiable fibrous forms from the soybean hulls (Fig. 4a). However, after the activation process with $\mathrm{ZnCl}_{2}$ there are cavities between the fibrous structures which play a positive role in increasing the specific surface area (Fig. 4b). These cavities, after activation, may be the result of the release of volatile compounds during the pyrolysis process. ${ }^{34}$

The Fig. $4 \mathrm{c}$ and $\mathrm{d}$ show the micrographs of the activated carbon after SP immobilization. The presence of small structures on the SP-AC suggested that SP remains clustered after the immobilization procedure.

X-ray powder diffraction (XRD) and FTIR spectra. The XRD patterns, recorded for the AC and SP-AC. Fig. 5a, reveal the 
Table 1 Summary of the catalyst nomenclature, its composition and specific surface area (BET), total pore volume, average pore diameter

\begin{tabular}{lllllll}
\hline Materials & $\begin{array}{l}\text { Carbon } \\
(\%)\end{array}$ & $\begin{array}{l}\text { Hydrogen } \\
(\%)\end{array}$ & $\begin{array}{l}\text { Nitrogen } \\
(\%)\end{array}$ & $\begin{array}{l}\text { BET } \\
\left(\mathrm{m}^{2} \mathrm{~g}^{-1}\right)\end{array}$ & $\begin{array}{l}\text { Total pore volume }^{a} \\
\left(\mathrm{~cm}^{3} \mathrm{~g}^{-1}\right)\end{array}$ & $\begin{array}{l}\text { Average pore diameter } \\
(\AA)\end{array}$ \\
\hline Carbonaceous precursor & 38.84 & 5.66 & 1.27 & - & - & - \\
Activated carbon & 67.65 & 3.45 & 1.88 & 1603 & 0.847 & 15.6
\end{tabular}

${ }^{a} \mathrm{~N}_{2}$ adsorption method. ${ }^{b}$ BJH desorption.
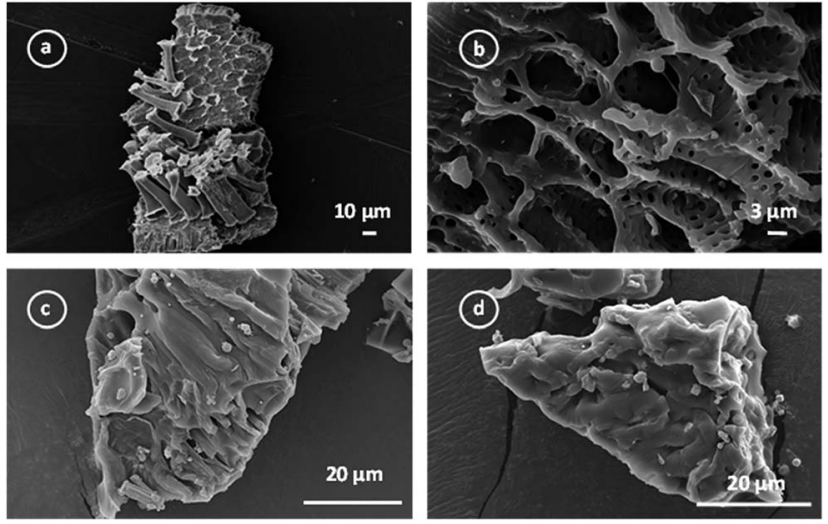

Fig. 4 SEM images of precursor (a); activated carbon after activation with $\mathrm{ZnCl}_{2}$ (b); activated carbon after SP immobilization at different magnifications (c) and (d).

presence of an amorphous halo centered at $2 \theta=23^{\circ}$ degree which is a common feature of non-crystalline structures typically present in activated carbon.$^{35,36}$ In addition, the XRD result confirms the absence of possible residual crystalline contaminants from the chemical activation process. The XRD pattern of SP-AC reveals the maintenance of non-crystalline structure characteristic of activated carbon, and also displays small peaks at $2 \theta$ values around $31^{\circ}, 34^{\circ}$ and $36^{\circ}$ that, by matching to JCPDS files (JCPDS 35-0735), are identified as the reflections of residual sodium hydrogen phosphate hydrate and other salts derived from the buffer solution. The presence of impurities was expected since the SP used in this work is a by-product without any previous purification stage.

The activated carbon and immobilized soybean peroxidase on activated carbon were characterized by FTIR spectroscopy. FTIR spectrum of pure SP enzyme displays absorbance bands
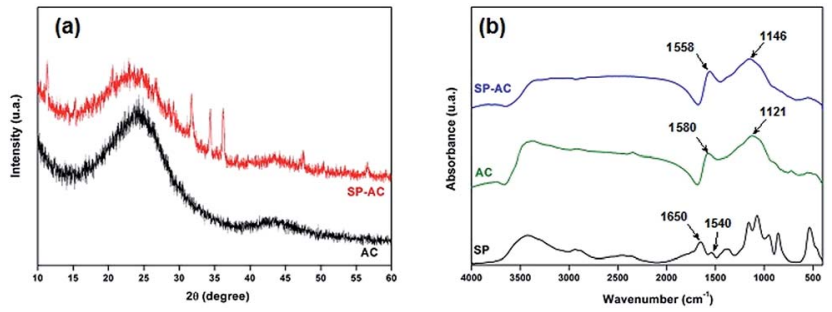

Fig. 5 (a) DRX diffractograms and (b) FTIR spectra corresponding to pure AC, SP-AC and SP samples. The SP pure analyses were added to the comparison. between 3000 and $3500 \mathrm{~cm}^{-1}$ that are attributed to the $\mathrm{N}-\mathrm{H}$ and $\mathrm{O}-\mathrm{H}$ stretching, respectively, whereas the $\mathrm{C}-\mathrm{H}$ asymmetric stretching mode is observed at $2930-2900 \mathrm{~cm}^{-1}$ (Fig. 5b). In addition, IR absorbance displays bands at $1640-1650$ and 1540$1550 \mathrm{~cm}^{-1}$, which are attributed to the amide I and amide II absorbance bands, respectively. ${ }^{37,38}$ These regions consist mainly of the $\mathrm{C}=\mathrm{O}$ stretching vibration of the backbone peptide bonds in proteins. ${ }^{39}$ The region between 1200 and $1400 \mathrm{~cm}^{-1}$ involves mainly C-H bending motions, ${ }^{40}$ whereas the $1260-1000$ $\mathrm{cm}^{-1}$ and $700-400 \mathrm{~cm}^{-1}$ absorptions are attributed to phosphate groups (impurities in the activated carbon matrix) and $\mathrm{C}-\mathrm{C}$ stretching modes, respectively. AC infrared spectrum exhibits a wide absorption at $3700-3200 \mathrm{~cm}^{-1}$ attributed to the presence of strong hydrogen bonds, i.e., $\mathrm{O}-\mathrm{H}$ stretching or water adsorption. The position of this band at lower wave numbers indicate the presence of strong hydrogen bonds..$^{38,42}$ Furthermore, the FTIR spectrum of AC displays absorptions at $1680-1480 \mathrm{~cm}^{-1}$ corresponding to the overlapping of stretching modes in aromatic skeletal and $\mathrm{C}=\mathrm{C}$ groups. The complex bands in the range from 1400 to $900 \mathrm{~cm}^{-1}$ are related to superposition of the following vibrational modes: $\mathrm{C}-\mathrm{H}$ symmetric and asymmetric bending, $\mathrm{C}-\mathrm{O}$ asymmetric stretching of aromatic ethers, esters and phenols, and $\mathrm{C}-\mathrm{O}$ in carboxylic acids, alcohols, phenols and esters or the $\mathrm{P}=\mathrm{O}$ bond in phosphate esters. Similar absorptions bands were observed for the SP-AC sample, however, with some subtle spectral changes owing to the SP immobilization. The FTIR spectrum of SP-AC is characterized by the maximum displacement of the absorption band from $1580 \mathrm{~cm}^{-1}$ in AC to $1558 \mathrm{~cm}^{-1}$ in SP-AC. This red shift is associated with changes in the functional groups present on the activated carbon owing to SP immobilization. In fact, this spectral frequency has been attributed to overlapping of two absorptions ascribed to the $(\mathrm{C}=\mathrm{O})$ stretching mode of the carbonyl group and associated with a combination of $\mathrm{N}-\mathrm{H}$ and $\mathrm{C}-\mathrm{N}$ stretching vibrations. ${ }^{37-39}$

Thermal analysis. Thermal analysis showed both samples presented one single event related to the backbone carbon oxidation, as confirmed by exothermic peaks present in the DTA curves (Fig. 6a and b). TGA curve for AC shows a weight loss of $92 \%$ between 490 and $590{ }^{\circ} \mathrm{C}$, whereas for SP-AC the similar residual mass was reached between 463 and $578^{\circ} \mathrm{C}$. In fact, DTG maximums were at 545 and $520{ }^{\circ} \mathrm{C}$ for $\mathrm{AC}$ and SP-AC, respectively. The combustion profile of activated carbon depends on several factors such as specific surface area, porosity and particle size, among others. It is important mentioned that, AC and SP-AC have the same carbonaceous matrix. Thus, this thermal shift is associated with the SP on the activated carbon 

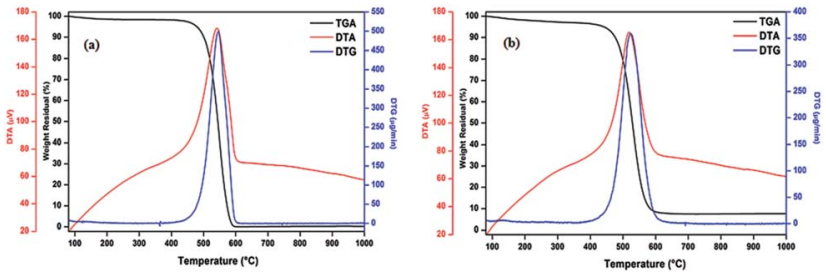

Fig. 6 TGA/DTG/DTA curves for AC as-prepared (a) and SP-AC samples (b).

surface. On the other hand, the residual mass for AC was slightly greater in comparison with SP-AC, $8 \%$ and $12 \%$, respectively. Such difference in mass loss confirms the presence of SP and its thermostable impurities in the activated carbon matrix.

Operational stability of immobilized enzyme. The viability of immobilized enzymes for industrial applications is dependent on whether the enzyme can be regenerated and consequently whether the biocatalyst can be reused. ${ }^{43}$ This makes the enzyme immobilization process highly attractive, due to the current demands of the biotechnology industry for the development of productive catalysts and new techniques that increase their shelf life. ${ }^{15}$

The SP-AC was used in 10 cycles and the performance of the immobilized biocatalyst was analyzed as to determination the peroxidase activity at the end of each cycle. The results obtained are shown in Fig. 7. It was observed that the activity of the SP-AC undergoes a decline from the first to the second cycle, becoming constant until the last.

To evaluate the amount of enzyme loss during the each cycle, the washing residue of SP-AC was collected and the residual enzymatic activity was determined. From the first cycle, no catalyst loss was detected, implying a strong bonding of SP on the support. Several authors suggest that the decrease in enzymatic activity after successive cycles is related to some enzyme leaching from the support. ${ }^{44,45}$ In this work, enzyme leaching after successive cycles was no detected, implying a strong bonding of SP on the activated carbon.

The decrease performance of the catalyst after each cycle may be attributed to the accumulation of the end-product

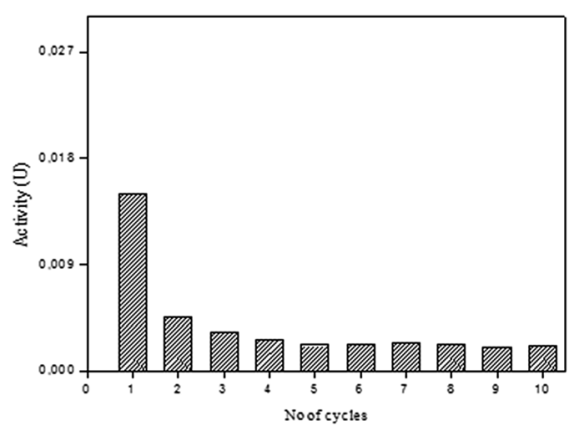

Fig. 7 Operational stability of immobilized soybean peroxidase in active carbon in the activity assays. Reaction conditions: $20 \mathrm{mg}$ of soybean peroxidase immobilized in activated carbon, citrate-phosphate buffer $\mathrm{pH} 6.0\left(0.1 \mathrm{~mol} \mathrm{~L}^{-1}\right)$, guaiacol $(1 \% \mathrm{v} / \mathrm{v})$ and hydrogen peroxide $(0.3 \% \mathrm{v} / \mathrm{v})$. polymer (formed during the oxidative polymerization of phenolic compounds by peroxidases) on the catalyst surface hindering the access of the substrate to the enzyme active site. $^{4,46}$

Considering that the enzymes are not stable during storage, presenting an activity decrease over time, in addition to the impossibility of reuse in its free form, soybean peroxidase immobilized in activated carbon obtained from enzyme extraction waste was capable of maintaining the peroxidase activity over repeated uses, which is attractive from an economic point of view.

\section{Conclusion}

The immobilization of enzymes has become a topic of great interest in different technological areas. In this study, a support for soybean peroxidase immobilization was synthesized from the waste itself generated during the enzyme extraction process, characterizing a closed production cycle with a total utilization of biomass and minimal waste generation, which complies with green chemistry principles. The synthesized activated carbon exhibits a high surface area $\left(1603 \mathrm{~m}^{2} \mathrm{~g}^{-1}\right)$, an important feature during the immobilization process. An immobilization yield of $100 \%$ was achieved after optimizing the reaction parameters (enzyme : support ratio of $0.05: 1 \mathrm{~g}$, pH 3.0 (citrate-phosphate buffer) at temperature of $40{ }^{\circ} \mathrm{C}$ for a period of $1 \mathrm{~h}$ ) and after 10 reuse cycles the immobilized soybean peroxidase still showed activity, a considerable aspect compared to biocatalysts in their free form, which cannot be reused. From the results obtained we concluded that soybean peroxidase immobilized on activated carbon is amenable to differentiated applications, such as in the biocatalysis, bioremediation, in clinical diagnostics, biosensor construction and other biotechnological industrial processes.

\section{Acknowledgements}

The authors acknowledge the use of the analytical instrumentation facility at Institute of Chemistry - University of Campinas, which is supported by the State of Paulo. This work was carried out with the support of the CAPES, CNPq and FAPEMIG.

\section{References}

1 J. Guo, T. Zhang, C. Hu and L. Fu, Nanoscale, 2015, 7, 1290.

2 J. Lima-Ramos, W. Neto and J. M. Woodley, Top. Catal., 2014, 57, 301.

3 M. C. Silva, J. A. Torres, L. R. V. Sá, P. M. B. Chagas, V. S. Ferreira-Leitão and A. D. Corrêa, J. Mol. Catal. B: Enzym., 2013, 89, 122.

4 J. A. Torres, P. M. B. Chagas, M. C. Silva, C. D. Santos and A. D. Corrêa, Environ. Technol., 2015, 37, 1288.

5 J. A. Torres, P. M. B. Chagas, M. C. Silva, C. D. Santos and A. D. Corrêa, Water Sci. Technol., 2016, 73, 39.

6 D. N. Tran and K. J. Balkus, ACS Catal., 2011, 1, 956.

7 T. Jesionowski, J. Zdarta and B. Krajewska, Adsorption, 2014, 20, 801. 
8 P. Saranya, S. Ranjitha and G. Sekaran, $R S C$ Adv., 2015, 5, 66239.

9 G. Merle, M. Seon-lutz, J. H. Lopes and J. E. Barralet, Part. Part. Syst. Charact., 2014, 31, 1091.

10 J. H. Lopes, M. Guilhou, B. Marelli, F. G. Omenetto, D. L. Kaplan, J. E. Barralet and G. Merle, J. Mater. Chem. A, 2015, 3, 19282.

11 F. B. O. Daoud, S. Kaddour and T. Sadoun, Colloids Surf., B, 2010, 75, 93.

12 U. Hanefeld, L. Cao and E. Magner, Chem. Soc. Rev., 2013, 42, 6211.

13 R. C. Rodrigues, C. Ortiz, A. Berenguer-Murcia, R. Torres and R. Fernández-Lafuente, Chem. Soc. Rev., 2013, 42, 6290.

14 S. A. Mohamed, A. A. Darwish and R. M. El-Shishtawy, Process Biochem., 2013, 48, 649.

15 S. Datta, L. R. Christena and Y. R. S. Rajaram, 3 Biotech., 2013, 3, 1 .

16 Y. Liu, Z. Zeng, G. Zeng, L. Tang, Y. Pang, Z. Li, C. Liu, X. Lei, M. Wu, P. Ren, Z. Liu, M. Chen and G. Xie, Bioresour. Technol., 2012, 115, 21.

17 L. C. A. Oliveira, E. Pereira, I. R. Guimaraes, A. Vallone, M. Pereira, J. P. Mesquita and K. Sapag, J. Hazard. Mater., 2009, 165, 87.

18 A. Demirbas, J. Hazard. Mater., 2009, 167, 1.

19 M. C. Silva, J. A. Torres, A. A. Castro, E. F. F. Cunha, L. C. A. Oliveira, A. D. Corrêa and T. C. Ramalho, J. Biomol. Struct. Dyn., 2016, 34, 1839.

20 A. A. Khan and D. S. Robinson, Food Chem., 1994, 49, 407.

21 P. M. B. Chagas, J. A. Torres, M. C. Silva and A. D. Corrêa, Int. J. Biol. Macromol., 2015, 81, 568.

22 A. P. M. Tavares, C. G. Silva, G. Dračić, A. M. T. Silva, J. M. Loureiro and J. L. Faria, J. Colloid Interface Sci., 2015, 454, 52.

23 R. S. Bretzlaff and T. B. Bahder, Rev. Phys. Appl., 1986, 21, 833.

24 R. Kandasamy, L. J. Kennedy, C. Vidya, R. Boopathy and G. Sekaran, J. Mol. Catal. B: Enzym., 2010, 62, 59.

25 A. Jain, V. Ong, S. Jayaraman, R. Balasubramanian and M. P. Srinivasan, J. Supercrit. Fluids, 2016, 107, 513.

26 M. C. Silva, A. D. Corrêa and J. A. Torres, Quim. Nova, 2012, 35,889 .
27 C. Cosio and C. Dunand, J. Exp. Bot., 2009, 60, 391.

28 M. A. Ahmad and R. Alrozi, Chem. Eng. J., 2011, 171, 510.

29 D. Angin, Bioresour. Technol., 2014, 168, 259.

30 M. Gonçalves, M. C. Guerreiro, L. C. A. Oliveira, C. Solar, M. Nazarro and K. Sapag, Waste Biomass Valorization, 2013, 4, 395 .

31 D. N. Tran and K. J. Balkus, ACS Catal., 2011, 1, 956.

32 A. Bhatnagar, W. Hogland, M. Marques and M. Sillanpää, Chem. Eng. J., 2013, 219, 499.

33 I. Fechete, Y. Wang and J. C. Védrine, Catal. Today, 2012, 189, 2.

34 Q. Miao, Y. Tang, J. Xu, X. Liu, L. Xiao and Q. Chen, J. Taiwan Inst. Chem. Eng., 2013, 44, 458.

35 Y. Chen, X. Zhang, H. Zhang, X. Sun, D. Zhang and Y. Ma, RSC Adv., 2012, 2, 7747.

36 P. Kalyani and A. Anitha, Port. Electrochim. Acta, 2013, 31, 165.

37 H. Zheng and X. Jiang, Asian J. Chem., 2014, 26, 685.

38 M. Prokopijevic, O. Prodanovic, D. Spasojevic, Z. Stojanovic, K. Radotic and R. Prodanovic, Bioprocess Biosyst. Eng., 2014, 37, 799.

39 S. S. Karajanagi, A. A. Vertegel, R. S. Kane and J. S. Dordick, Langmuir, 2004, 20, 11594.

40 M. Khajehpour, J. L. Dashnau and J. M. Vanderkooi, Anal. Biochem., 2006, 348, 40.

41 M. Ghaedi, B. Sadeghian, A. A. Pebdani, R. Sahraei, A. Daneshfar and C. Duran, Chem. Eng. J., 2012, 187, 133.

42 K. Ramani, S. Karthikeyan, R. Boopathy, L. J. Kennedy, A. B. Mandal and G. Sekaran, Process Biochem., 2012, 47, 435.

43 I. V. Pavlidis, T. Vorhaben, T. Tsoufis, P. Rudolf, U. T. Bornscheuer, D. Gournis and H. Stamatis, Bioresour. Technol., 2012, 115, 164.

44 Y. Cao, L. Wen, F. Svec, T. Tan and Y. Lv, Chem. Eng. J., 2016, 286, 272.

45 R. Roto, Y. Yusran and A. Kuncaka, Appl. Surf. Sci., 2016, 377, 30.

46 M. C. Silva, J. A. Torres, F. G. E. Nogueira, T. S. Tavares, A. D. Corrêa, L. C. A. Oliveira and T. C. Ramalho, $R S C A d v$, 2016, 6, 83856. 